\title{
3 \\ Changing Standards of Living: The Paradoxes of Building a Good Life in Rural Vanuatu
}

\author{
Rachel E. Smith
}

\section{Introduction}

There have been big changes_-'good houses', solar lights—we no longer have the same living standards as before. (Seasonal worker)

Before, in the 1970 s and 1980 s, life was totally different ... We no longer have the 'good life' of before. (Father, school cook)

The construction of a 'good house' had become a preoccupation for seasonal-worker households in my fieldwork site of Lamen Bay on the island of Epi, and the small offshore Lamen island, by the time of my arrival in Vanuatu in November 2011. The day after I landed in Lamen Bay, my host mother, Mary, ${ }^{1}$ took me on a tour along the dirt road that looped around the settlement, pointing out the many new houses and more under construction. An educated local woman, Mary acted as an administrative agent for the largest recruiter of seasonal workers from Epi in New Zealand's Recognised Seasonal Employer (RSE) temporary migration program. She told me later that she always urged the seasonal workers she recruited to build a 'good house', to install solar power and to prioritise their families with the money they earned overseas.

1 To protect the anonymity of my interlocuters, the personal names in this chapter are pseudonyms. 
THE QUEST FOR THE GOOD LIFE IN PRECARIOUS TIMES

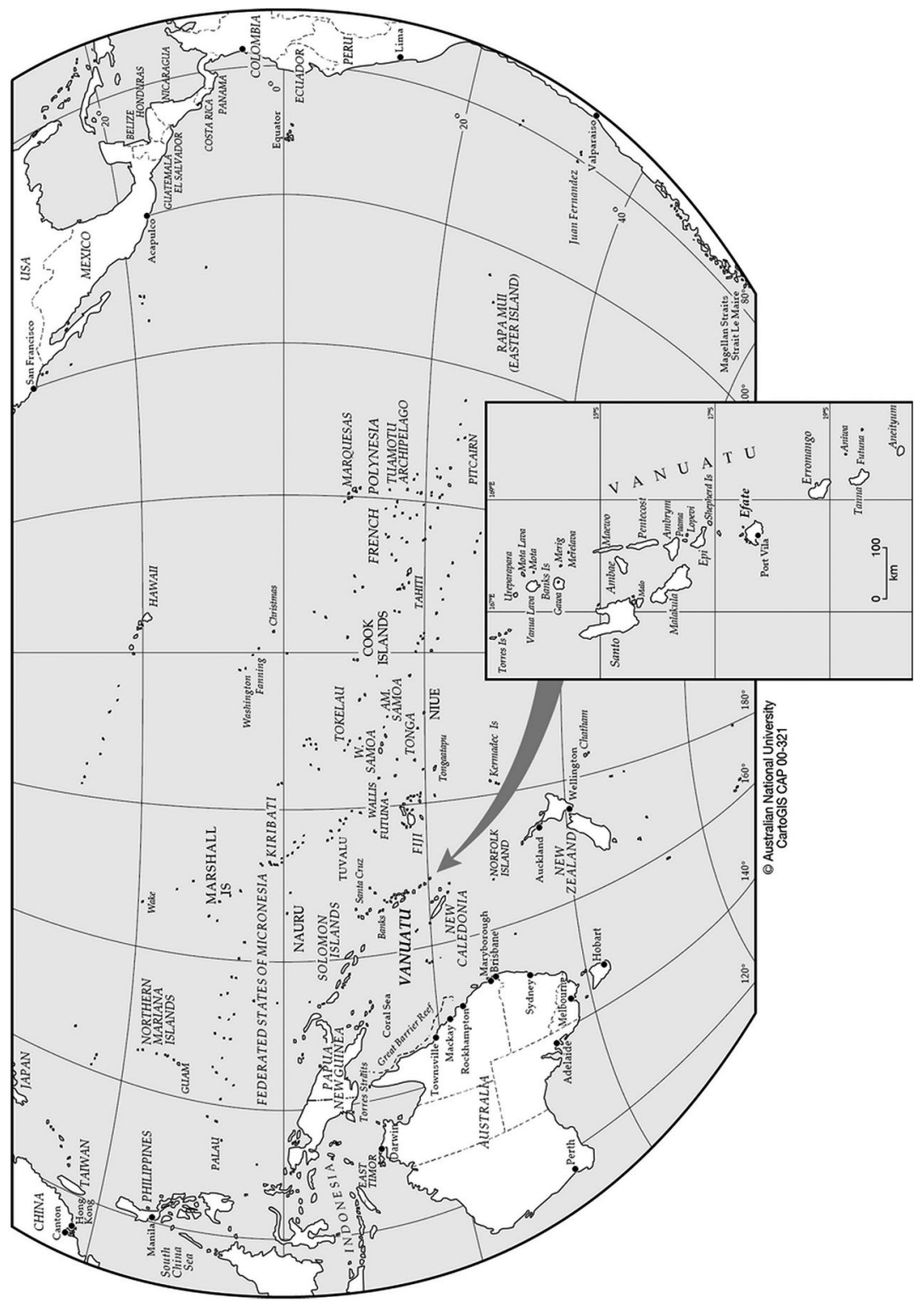

Figure 3.1: Vanuatu, South-West Pacific Ocean

Source: CartoGIS, College of Asia and the Pacific, The Australian National University. 
Lamen Bay is located on the north-west coast of Epi island, central Vanuatu, so named after the small offshore Lamen island, whose inhabitants travel back and forth to the bay to cultivate gardens. Since around the 1960s, increasing numbers of Li-Lamenu ${ }^{2}$ have been moving across to the mainland more permanently. Unlike Epi mainland to the south and east, Lamen island and Lamen Bay are densely populated and there are growing worries about future land shortages. Within Vanuatu, Lamen Bay and Lamen island are well known as communities with a high degree of engagement in New Zealand's horticultural seasonal-worker program. When New Zealand's RSE program was launched in 2008, two major employers began to recruit in the area and several others followed. By the time of my fieldwork (November 2011 - March 2013), seasonal work had become an important means of making a living for most families. A household survey I conducted in 2012 revealed that over twothirds of all households (including those ineligible due to age) had had at least one member engage as a seasonal worker, many of whom were, by then, returning for their fourth or fifth season.

For Li-Lamenu seasonal workers, the construction of a 'good house' and the payment of school fees are the most common reasons for working overseas; this reflects a collective desire to improve standards of living and secure a future for the next generation in a wage economy. At a community council meeting a few days after my arrival in Epi, the chief and the chairperson led a discussion to thank the seasonal workers for the development they had brought. The chairperson stated, 'many thanks to those of you who have created development with your houses and the things in which we can see that now this place is developing'. The chief affirmed this sentiment, declaring that 'it is a good thing that we go and come and make ... our homes. We have changed Lamen Bay: all the buildings'.

2 Just as the people whose ethnic origin is from Vanuatu are known by the demonym 'Ni-Vanuatu', I refer to people who identify as originating from Lamen island as Li-Lamenu, meaning 'people of Lamen' in their vernacular. 
THE QUEST FOR THE GOOD LIFE IN PRECARIOUS TIMES

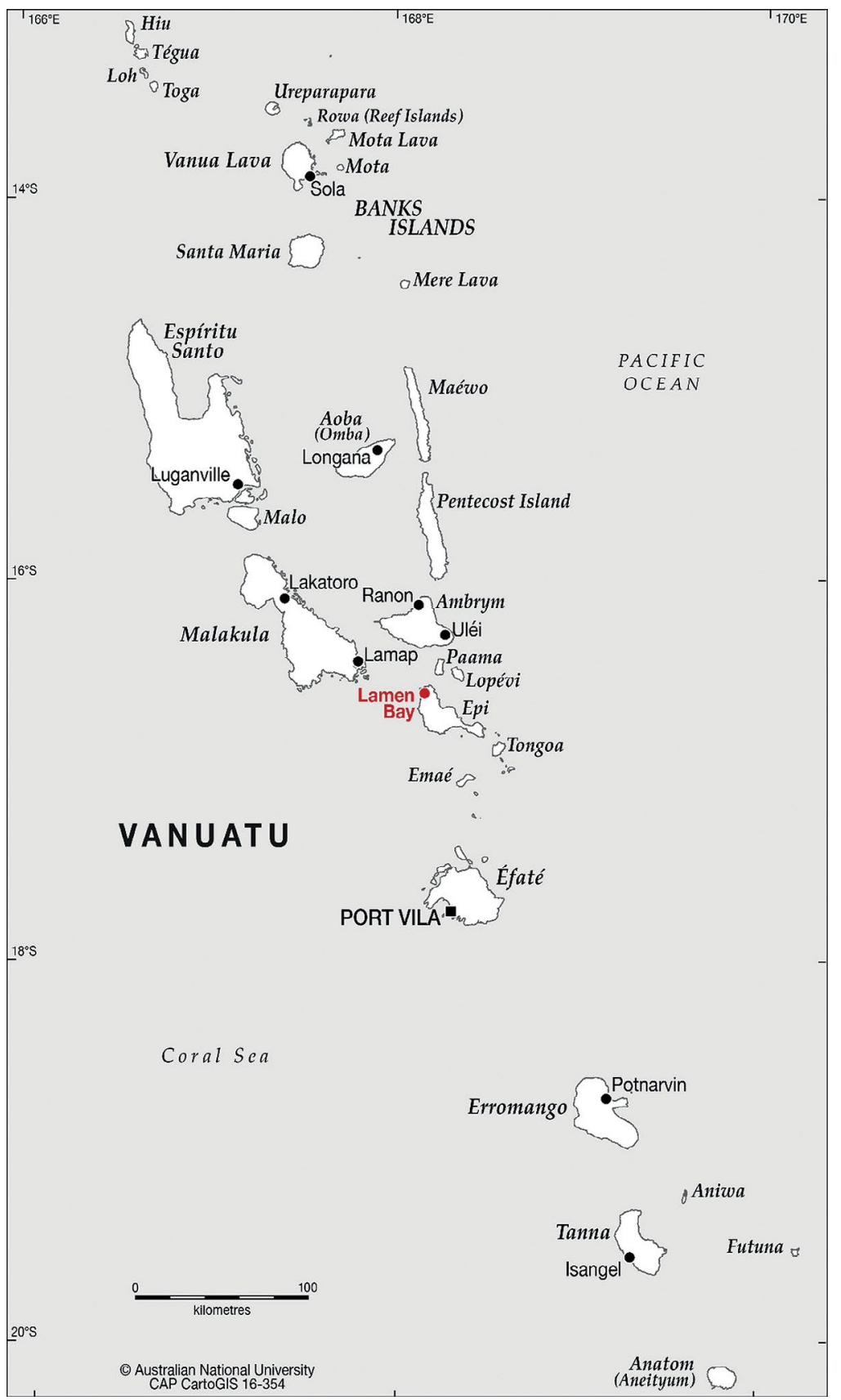

Figure 3.2: Map of North and Central Vanuatu, with Lamen Bay in Epi Marked

Source: CartoGIS, College of Asia and the Pacific, The Australian National University. 
However, not all of the changes associated with seasonal migration were as welcome as the new housing. The actions of seasonal workers were often evaluated against moral as well as material standards, as being more or less conducive to living together well. Both the chief and the chairperson admonished seasonal workers for neglecting to contribute money and labour to community and church projects. The chief said, 'whose future is this for? It's for your own children's future. We should be glad about New Zealand ... I want to see good things everywhere we go'. He advocated a selective approach to incorporating foreign attitudes and behaviours. For instance, although the workers had learned to follow rules in New Zealand, such as regulations on fishing, they often ignored the chiefs' rulings on reef prohibitions $(t a b u) .{ }^{3} \mathrm{He}$ added:

We need to change ourselves in some ways. We shouldn't go just for money: we need to change our attitudes. Anything they have that is better, you bring it with you.

As the chief's statement suggests, Li-Lamenu do not indiscriminately welcome outside goods and practices. Rather, they seek to incorporate those actions and objects deemed moral 'goods' from outside, while maintaining traditional or autochthonous kastom (custom) practices and modes of relating that are seen as essential to living in peace and respect with kin. However, this envisioning of the 'good life' and 'good development' as some combination of kastom and material and social 'goods' from the 'outside' is open to deliberation and contestation.

Li-Lamenu conceptions of the moral life fit well with those of Mauss (2007) who observed that 'morality is the art of living together, and it can be recognised by the presence of the notion of the good' (p. 156). The trouble is that 'the good' is always subject to contest and change; thus, the quest for, or the question of, the good life requires 'moral reasoning, through the contrary and contradictory value standards of the good' (Sykes, 2012, p. 173). The quest for the good presents Li-Lamenu with a number of problems and dilemmas. For one, standards of the good are always subject to change, corresponding with economic, political and religious transformations. Second, the matter of the good is always subject to contestation; a good for one, or in one context, may be a bad for another. Third, the pursuit of the good can often lead, paradoxically, to the introduction of 'bads'.

3 Words in Bislama vernacular are in italics, while vernacular Lamen terms are also underlined. 
Indeed, engagement in overseas seasonal work is repeatedly said by Li-Lamenu to have a 'good side' and a 'bad side'. Justifications for channelling money into houses, land and school fees revolvearound securing a future for the household and community 'development'. However, this pursuit of standards of living gives rise to a number of contradictions including land disputes and scarcity, broken homes, withdrawal from community work and a perceived decline in respect and reciprocity. These different visions of the good life relate to different valuations of space and time, corresponding with idealised pasts and futures. A vision of the good life associated with the household's material success in a cash economy can come into tension with, or threaten, a conception of the good life associated with an ancestral past, in which the good life- living together well' (Gregory, 2013, p. 137) —is understood as maintaining mutual relations of respect in line with customary expectations.

In this chapter, I discuss the ways in which Li-Lamenu negotiate the paradoxes of building a good life, and how they navigate contradictory values and changing standards of the good. First, I discuss how constructing a 'good house' is seen as a moral as well as a material 'good', standing for household security and prosperity in conditions of economic and environmental uncertainty. While a house is seen as a self-evident 'good', it gives rise to tensions and paradoxes concerning the possibilities for living together well with kin, as I describe in the second section. Workers are also investing in the education of their children to the end of secondary school, sometimes even into tertiary or higher education. In the third section, I discuss how workers aim to secure a place for their children in an increasingly wage-based economy and to improve or maintain their children's standards of living, thereby mitigating anxieties over land scarcity and environmental disasters. However, this vision of the 'good life' in terms of improving material standards of living for one's household as well as the next generation is often met with a counter narrative in which a good life, as founded on relations of respect, is in decline. In the final section, I discuss how, although material standards are changing, people are concerned to retain relations of respect as crucial to leading a good life and living together well. 


\section{Changing Standards of Living}

The 'good house' is frequently associated with improvements in 'standards of living', an English phrase often incorporated into Li-Lamenu expressions of their desires. Standards of living are moral as well as material and ideas of the good are historically and socially particular. Over 25 years ago, Rodman's (1985a, p. 275) informants on the island of Ambae (Aoba in Figure 3.2), North Vanuatu, were distinguishing houses in terms of their 'goodness', concluding that 'for most people in Longana, a "good" house is a simple structure, perhaps 15 feet square, with a corrugated iron roof, cement floor, and walls of woven bamboo'. Li-Lamenu people today also aim for a 'good' house, but most would no longer be satisfied with the house Rodman described. For a New Zealand returnee, a 'good' house has, perhaps, three to six bedrooms, a separate 'sitting room' constructed entirely of durable materials, a corrugated metal ( $k a p a)$ roof, walls of concrete or a combination of concrete and kapa, and a cement floor. Ideally, it also has a front veranda, one or two solar panels and a large rain tank.

Following the introduction of the RSE program in 2008, there was a rapid proliferation of 'good houses' in Lamen and Lamen Bay. My December 2012 household survey revealed a rapid transition to more durable imported housing materials on Lamen island. Between 2008 and 2012, 46 'good' houses were built, compared with just four in the five years prior. Houses often take at least three successive seasons to build; many were coming to completion during my fieldwork, while others were still under construction. A comparison with national census data (Vanuatu National Statistics Office, 2009) reveals that the use of traditional plant materials for walls and roofs was halved in the three years prior to my survey. There was an even more dramatic transformation in transition to electric light sources; kerosene lamp use dropped from 71 households in 2009 to just eight in late 2012. In the same period, solar lighting increased fourfold.

Household and residence patterns have taken shape together with changes in moral and material standards of living over the last 150 years. Changes in houses and domestic spatial patterns have materialised aspects of historical and social transformations and changing identities (Rodman, 1985a, pp. 269-72). In the colonial period, spatial and residential configurations made visible and tangible the conversion of people to a new moral temporal order (Mitchell, 2013, p. 292), which was brought about through the subdual of warfare, reduction in fear of sorcery and spirit attacks, and missionary influence. Prior to European trade 
and conversion to Christianity, people lived in small hamlets in clusters of between one and three clans. Encouraged by missionaries and colonial officers, pacification and a desire for trade, clans began to concentrate into adjacent yards (rove) nearer the sandy shoreline, divided by low dry-stone walls. Men were encouraged to leave men's houses (nakamal, kumali) and live with their wives as a conjugal unit, eating with their families and encouraging more household nucleation (Rodman, 1985a, p. 272). Pigs were fenced and older people today recall how community work parties kept shared spaces clean and tidy.

The household's form and function and its relationship with wider kin and community has changed over time as a result of outside influences, including the colonial promotion of nuclear family models and ideas about health, hygiene and economic transformations. The precolonial $\mathrm{Li}-$ Lamenu house $($ kanayum $a$ ) featured a low saddle roof that stretched to the ground on either side, with a small entrance door at one end, and a cooking fire inside. Missionaries and colonial officers arriving in Vanuatu from the mid-nineteenth century saw precolonial houses as dirty, dark and smoky; they enforced new 'civilising' moral and material standards that promoted hygiene, cleanliness, ventilation and light (Jolly, 1991, p. 39; Rodman, 1985a, p. 272). Gradually, during the late colonial period, kanayum $a$ were replaced with upright houses with pitched sago (natangura) thatch panelled roofs and a more familiar, boxy European-style shape. The walls were made of woven bamboo or, more typically for Lamen, wild cane. They often had an A-framed house style, along with separate "kitchen houses' and private drop toilets. Some people told me this transformation largely took place in the 1950s-60s, triggered by an infestation of small millipedes, known in Bislama as kruked. This may be true; however, this transition also took place on islands across Vanuatu and, it would seem, largely due to colonial and church influence. Many men would have become familiar with new technologies and materials during service in World War II and further changes were introduced by post-war health and development initiatives (Taylor, 2008, pp. 144-45).

People on Lamen also experienced new construction techniques and styles when a Presbyterian missionary and his family took up residence on the island in 1948. The missionary, Graham Horwell, soon began work on a large European-style lime house, for which he summoned an architect and a carpenter from New Zealand. When the new mission house was finished, a visitor described how it drew considerable attention from the Li-Lamenu congregants: 
A house is built for him that is necessarily large and airy for health reasons. The natives eye this mansion with envy ... to them he appears to want for nothing ... the natives try to sponge on him for all manner of things ... He certainly sacrifices many things which we regard as essential to a comfortable life. (France, 1953, p. 110)

In the decades that followed, some Li-Lamenu men were trained as carpenters and employed by the district officer to construct buildings elsewhere in the district. Others had experience of construction in Noumea, New Caledonia, a popular destination for temporary migration in the 1960s and 1970s. When they returned, they often spent their money on housing materials, constructing European-style houses. Some of these houses were built from manufactured materials or lime. Moreover, they were built using styles and techniques that serve as testament both to the influence of the mission house and the increasing familiarity with urban and colonial architecture.

More than three decades after independence and the departure of foreign missionaries on Lamen, there remain strong associations of the 'good house' with moral and material development. The 'lighting up' of the good house seems to have assumed a particularly spiritual significance, recalling the transition between a common Melanesian Christian temporal idiom of the time of 'darkness', being the pre-Christian past, and the 'light' ushered in by the missionaries (Jolly, 1991; Tonkinson, 1982, p. 51). In fact, the opportunity to work overseas and to change one's living standards is often said by Li-Lamenu people to be a 'blessing', suggesting that they see it as part of God's plan. Many claim that the opportunity to participate in the seasonal work program is a legacy of the last missionary, as it was Horwell's relative who first recruited seasonal workers from Epi.

Many material changes are seen as self-evidently 'good' for their perceived convenient and pragmatic benefits. Solar panels and rain tanks are especially valued material outcomes of engagement in overseas work. Rainwater run-off from a metal roof can be collected in a tank; this is especially useful on Lamen island where access to potable drinking water is limited. People often comment that solar-powered electric lighting allows them to carry out activities at night that they could not have done when they relied on kerosene lamps. However, the transition is not advantageous in every respect of material comfort and practicality. Metal roofed houses, especially those with metal walls, are much hotter than the cool and airy houses built of natural materials. As such, people 
tend to avoid spending any length of time inside until they retire to bed, preferring to congregate outside in the shade, under a veranda or perhaps in a cool, thatched kitchen building.

Perhaps the most common reason people give for building a 'good house' is the durability and strength of imported materials, which are associated with security for one's family. A 'traditional' or 'local' thatch house might last only two years, whereas a 'permanent' or 'semi-permanent' house may last 20 years before the kapa roofing sheets have to be replaced. Additionally, 'permanent' houses are less likely to need maintenance during the period the seasonal worker is away. One married seasonal worker, who faced criticism for choosing to return to New Zealand when his wife was seriously ill, legitimated his decision by stressing his desire to complete the house, then under construction, as a means of demonstrating his care and nurture for his wife and children:

Most of the workers that go over there, their goals are to build a house, light up a house. When you stay in a kastom house, it is a short time before you must build another ... When you build a house-a 'good one'-you no longer worry about your family, your family has a good place to live when you are away.

As this statement articulates, seasonal workers often emphasised protection for their family when justifying their decisions. The most common reason for building a good house was to provide protection from cyclones, both for the household and for less well-off relatives. The following news item (Radio New Zealand, 2015), which is based on an interview with a Li-Lamenu nurse following a severe, category five cyclone, illustrates the value of safety from such disasters:

If it were not for those who went to New Zealand and built these big buildings I can say [that] many people would have died because we would have been running from house to house and we would have been killed by the flying debris. But these big buildings that we have saved the lives of everyone on Lamen island.

Due to the prevalence of seasonal work opportunities in Lamen and Lamen Bay, cumulative household accomplishments have, generally, been welcomed as conducive to the development of the community and island in the form of material standards of living. Judged by material standards of living, the durable 'good house' has come to stand for a certain conception of the good life and the future wellbeing of its occupants; however, this can be contested against other standards of the 'good'. 


\section{Household Goods and Bads}

While the durability and practical aspects of the good house are almost taken for granted as 'good', moral evaluations of their occupants are underpinned by whether their behaviour is deemed conducive to maintaining good social relations. In an interview, Chief Waiwo reiterated common reasons for the positive valuation of the 'good house', but also described how the house and the 'goods' it contained could become 'bads' when they were used in a way that was counter to living together well:

Before there were few [good houses], but now there are many, which is good. Their families are safe. They carry solar, and do good things. But sometimes they use their solar in a bad way: they carry noisy things. When that happens, people no longer have respect: there's mourning, but there's music in another house. It means there's no respect for others. Then you find out they are trying to 'compete': who can carry the loudest? Some things are good, but some things are like that.

Household 'goods' are only considered 'good' when they appear to bring benefits without having negative effects on others. In this sense, the kinds of effects termed '(negative, consumption) externalities' by economists (and some cultural economists) (Callon, 1998, p. 246) can be seen as integral to value creation and realisation from the point of view of the domestic moral economy in which the moral grounds of value depend on respect, which is crucial to living together well.

Li-Lamenu frequently remarked that before the rise of the RSE program they could not have imagined having a 'good house' or electric lighting. Most workers only had basic education, and many perceived their access to previously unavailable amounts of money through remittances as akin to closing a gap between 'haves' and 'have-nots'. For them, New Zealand work meant that people who schooled to Class Six (primary level) could now build houses that, before, were mainly only achievable for educated teachers and government workers.

'Good houses' achieved through seasonal work are not necessarily markers of class distinction; yet, in reflecting regional disparities in work opportunities and a shift away from reciprocal patterns towards household accumulation, they may create foundations for further economic differentiation in the future. Spending on the house and land is a means to allocate remittances in such a way that it allows household accumulation without entailing the types of criticism reserved for 
individual consumption. However, it also limits the wide dispersal of remittances to kin networks (Gamburd, 2004, p. 180). This raises the more general question of whether the good house reflects a shift away from a kin-ordered morality towards a more nucleated household-centric moral order. Rodman (1997) identified a similar transition towards household nucleation in rural Vanuatu, noting:

In the past, a house expressed connection to the community; now it expresses the importance of nurturing the nuclear family and of material success. A 'good provider' under these changed circumstances turns inward toward the household more than outward toward the larger social unit. (p. 227)

Changes in housing and residence can be seen as a concrete manifestation of changing social relations; the shift in emphasis of the distribution of time and resources from a deferred return in kind within kin networks, to more immediate and household-oriented transactions, can be seen in the construction of the fabric of the house itself. The construction of a thatched house is an event involving wide networks of kin and is tied up with acts of reciprocity of food and labour. When building a thatch house, the household gather together a wide circle of kin and neighbours whose collective efforts mean that the build can be completed in just one or two days. The women pre-prepare the materials and then get to work cooking food to feed all those who contribute; the helpers, in turn, can expect reciprocal assistance in the future. By contrast, permanent houses demand a certain level of technical expertise. Often a local carpenter, albeit usually a kinsman, is employed for a considerable fee. The demand for a 'good house' has provided impetus for the commoditisation and division of labour, which has undermined the principle of reciprocity of work. Today, people often complain that if you ask someone to come and help with a domestic task, they will expect payment.

Good houses are often built in secluded spots, away from the tightly packed yards where clan members have tended to live side-by-side. The desire for a 'good house' is leading to a spatial dispersal of households, as some households are identifying larger and more secluded areas of land on which to build a 'good house'. The attraction of proximity to roads and amenities, the convenience of not having to canoe or pay for boat rides, as well as more opportunities to obtain money, are leading many to move to Lamen Bay where the houses can be large and spaced far apart, suitable for creating secluded private yards with lawns and flower gardens. Further, there is an increasing quest for higher ground due to anxieties 
over climate change and natural disasters. These factors are contributing to the increasing turnover of land previously used for gardens or coconut plantations to residential land. This change in land use appears to be exacerbating the problem of land scarcity and food insecurity; on a recent return visit to Lamen, a pair of brothers told me that they were worried about the loss of garden land and would encourage their sons to build on the small island.

Across Vanuatu, the affective value of place (ples) is crucial to social identity; good houses can be seen as a long-term investment in remaining part of the community. Conversely, the 'good house' can become an object of social conflict and moral disapproval when the land identified for its foundations is disputed. Indeed, land disputes between $\mathrm{kin}^{4}$ were said to be intensifying, and it was very often the earmarking of plots on which to build new houses that triggered these conflicts. During my fieldwork, there were at least two occasions of vandalism of property on disputed sites, and other planned houses left unbuilt or abandoned due to ongoing disputes. Perhaps the fact that the houses represent fixed investments that stake a long-term claim on the land means that they are more objectionable and contested than the more mobile and temporary houses of homegrown materials that could easily shift according to different circumstances, or shifting plots of garden land that were more shareable and short term?5

New spatial arrangements emerging through the founding of 'good houses' appear as a process of privatisation of land and space and a transition from communal shared 'yards' towards more private properties. Further, it appears that these spatial reconfigurations may be mapping changing kin relations and a shift from clan to household as the locus of economic concern. Ward and Kingdon (1995, pp. 1-2) suggested that settlement patterns changed as people's efforts became more directed at self-interest and the contracted nucleated family group, rather than extended kin and the wider community, and as economic relations, previously organised through reciprocal obligations, became increasingly mediated through money (cf. Martin, 2007, pp. 49-50; 2013, pp. 72-73). In Vanuatu, Jolly (1989, p. 230) reported that on Pentecost island, richer families tended to build isolated homesteads outside the village; she suggested that such a move could be a partial withdrawal from kin networks of generalised reciprocity.

4 For more on land tenure and disputes in Lamen Bay, see Smith (2017).

5 Use rights to land for making a garden or building a thatched house could be allocated to clan or kin members according to need and stages in the life cycle (Rodman, 1985b, p. 276). 
In an effort to avoid disputes and strengthen their tenure on a residential plot, some people try to secure land through formal transactions. Although these transactions take a customary form and are between kin, they involve increasing sums of money and written deeds, and appear to fix household allocations of land. One young couple, David and Rita, performed a transaction in 2012 to their clan chief and his sons to pay for a piece of land on which they were building a new house. They had begun to construct their new house on the site in 2010 after David returned from New Zealand for the first time. The site was chosen because it was on higher ground and offered protection from tidal waves and disasters; however, Rita told me that their primary motivation for making the transaction was to help safeguard the future of their two children and to prevent them from being pushed off the land due to a dispute.

The fact that Li-Lamenu are increasingly fixing more permanent stakes in the land in the form of durable houses may be part of wider processes of household nucleation and individualisation of land tenure and emphasis on intergenerational transfers (cf. Ward \& Kingdon, 1995, pp. 1-2). Rita said that, in the past, 'the ancestors were good' and would give land to friends or family that needed it. She suggested that, perhaps due to the influence of waetman (white people), Li-Lamenu people now expect cash payment. She said that she worried about her children's future, especially if they had no land, although perhaps if they were well educated and managed to obtain good jobs in town they would be alright. These are common concerns among Li-Lamenu parents who worry about land scarcity and disputes, and increasingly look to education as a means of securing a place for the next generation in a changing economy.

\section{Stronger Foundations for the Future? Investing in Schooling}

The construction of a good house is not the only foundation for a future good life that migrants seek; educating one's children is seen as an investment in the good life of future generations. Seasonal work opportunities are valued for allowing parents to discharge school fees, and many parents are able to fund their children's education through to secondary and even tertiary education. Payment of school fees was the second most common stated expenditure of remittances in my survey, and is often considered the main driver for workers to keep returning to work, even after a house is completed. 
Like the house, expenditure on school fees was morally valued over shortterm consumption and imports deemed to undermine aspirations for a good life. A primary school teacher at Lamen Bay indicated that some of the blame for a perceived decline in children's behaviour fell on seasonalworker parents buying them unnecessary material items:

Many times, when the parents come back from New Zealand, they bring things like stereos, videos, mobile phones, and DVD players for the children. It really distracts children's interest from their studies at home ... It's really a big issue ... The parents should only carry things that are good for the child, but the child says, 'I want this, I want that', and they don't realise they are creating a big problem.

Unlike the good house and school fees, other kinds of consumption and expenditure were often negatively valued as a waste of money or for undermining moral behaviour. One returned seasonal worker and mother of three said:

When I came back the two children said, 'oh mummy, when we visit other children whose fathers have come back from New Zealand, they have this and they have that. They have just about everything'. But my reply was that 'you must get a good education, that's my plan' ... In my experience, those children whose fathers go to New Zealand: their lives are different. But in my home, I don't want my children to have all these things. I want my children to live a 'local life', so their thoughts remain good all the time. So, when I came back, they asked me, 'what did you bring for us?' And I replied, 'the things I brought are clothes, and money just for paying school fees, so I bought things to help your future'.

The primary school headmaster saw the concrete house as a less than permanent solution to a future good life. In his view, it was school fees that truly would provide a firm foundation. He told me that parents must prioritise a child's education, as it may be the only means to enable them to achieve and maintain the improved standards of living that the parents were striving for in the long term:

If this [RSE] scheme in New Zealand stops, where is your investment, the money for which you worked hard? If the scheme closes tomorrow, everyone will see that you worked to invest in your children, and too, the child will be able to support himself because he has a strong foundation. But if it is all for a house and solar, the child will not be able to achieve that if the scheme stops. It is better if you support the child in their schooling. 
The class teacher reiterated to her pupils that the standards of living brought about through seasonal work could not be maintained forever:

I keep telling the pupils in the classroom, 'don't you think this scheme will last forever. It will stop. And if you don't have an aim for your education, if you think that when you finish school you will go to New Zealand, then one day you will find it really, really hard, because one day this scheme will stop. It's not like your land, which will always be there to make gardens on. This scheme belongs to different people'.

However, while many Li-Lamenu realise that the scheme may be shortlived, and are using the money to invest in their children's education, they do not feel they can rely on the fact that the land will 'always be there' for gardens either. Li-Lamenu parents' anxieties about securing a place for their children in the wage economy is often framed in terms of land scarcity or insecure tenure, which makes them fear that there may not always be enough land for the rapidly growing population to provision themselves. Anxieties over land shortages and disputes, exacerbated by high population growth and fears about climate change, are causing parents to pin their hopes for their children's security on their education and employment in the wage sector.

Changing material standards of living creates pressure to maintain or better those standards. The headmaster suggested that if the next generation are unable to maintain or further those standards attained by their parents, they may find themselves in a precarious situation, neither able to make a living like their forebears, nor succeed in the wage economy:

I keep telling the Year 8s: 'You must get a good education, because it's not good if you stay here, while your parents have flat screens and solar lights and everything, but when you grow up and you get married, you are using kerosene lamps. It will look bad, because you won't be able to use the same lights as the others, because you are used to a "good house". When they get married, if they don't get a good education, and the [seasonal migration] 'scheme' is closed, then these children won't be able to live the same life that their parents provided for them. And for them, reaching that standard will be hard, because they don't have the same knowledge that their parents had. And when you see the children today, you see they don't work like the older people did in the past. 
As the headmaster implied, while schooling is often understood as preparing children for opportunities for wage work, it is seen as coming at the expense of acquiring knowledge and horticultural techniques that would make young people accustomed to working on their land, as their grandparents did.

The emphasis that parents place on education both contributes to, and is motivated by, youths' disinclination or inability to take up subsistence gardening in the future. Youths are increasingly undertaking secondary school, which involves them leaving the island and taking up residence in boarding schools. Living away from home, often at a great distance, they do not learn the gardening skills that were once essential to making a living. A secondary schoolteacher told me that due to the United Nations Millennium Development Goals, the government was keen to progress every child to at least Year 9. He felt that this plan was detrimental because many youths who were struggling in school, or who had little interest in education, were being encouraged to continue even though they were unlikely to find employment. It was his view that such children were better off returning home and learning traditional cultivation techniques; he felt that it was 'too late' to learn such skills past adolescence.

Educating their children allows Li-Lamenu parents to imagine a future with a future: one, they hope, that will not only lend them security in their older age, but also different standards of living for the generations that follow. However, this conception of a secure future is premised on different ways to make a living and types of mobility. This vision of a 'good life' requires reimagining Li-Lamenu social relations and ways of 'living well' that may be increasingly incompatible with possibilities for living together in one place. Rather than work the land, it seems that youths will be more likely to go to town in search of work or opportunities to work overseas. The increasing education of children to final years of secondary schooling and even into tertiary education suggests that the future of Lamen may be one that is economically differentiated and based on urban-rural flows. This is likely to be a process that creates 'winners' and 'losers'; given the limited opportunities for gainful employment, there is little guarantee that one's child will be able to obtain well-paid wage work in the future. While those who are successful may become the urban elites of tomorrow, older generations fear that a youthful population, disinclined towards garden work, but unable to secure a well-paid job, would drift to town, struggle to get by and get involved in trouble. Increasingly, youth are seen to be adopting foreign lifestyles and ignoring kastom, thereby threatening a conception of the good life that is seen as living together well with kin. 


\section{Losing Respect}

When you ignore the small things, it builds a big weakness. Now the community will always be in a mess. The power of our culture has been declining every year, since 1989 . Now all the children act as if everywhere is a 'free zone'. (Father, gardener)

If you have respect, you will have a good life. The youths are strong headed: they don't know how to make a garden and they always disobey. They don't have respect. When we die, it will be even worse. Lamen won't be like it is today. (Church elder, grandfather)

Most Li-Lamenu agreed that housing and education were self-evident 'goods' associated with community prosperity and development and securing a long-term future in a changing environment. However, most also feared that the indiscriminate pursuit of imported modern goods also threatened to undermine a conception of the good life rooted in an autochthonous past (albeit one re-imagined to be compatible with Christian values). While most people advocated the incorporation of particular types of material goods and practices, many were concerned about a moral decline and a lack of respect associated with the acquisition of foreign items and lifestyles at the expense of social relations based on ideas of respect for others, and for ancestral knowledge and practices, or kastom.

Discussions about the 'good life' in terms of living together well with others often revolve around ideas of respect (rispek, kohoyana). As in the quotations above, it is common for people to lament a decline in respect and the 'good life' of the past. Despite the increasing value placed on education as a means to securing a good future, many people worry about the effect of exposure to foreign things and knowledge on 'younger generations' regard for the respectful demeanour and customary practices that are understood to maintain good social relations. The common complaint about a decline in respect among young people not only denotes a lack of deference to authority, but also a lack of observance of avoidance behaviours, ignorance about obligations to kin and a loss of knowledge associated with how to perform kastom.

At 'Children's Day' in 2012, a Presbyterian Church elder addressed the children, saying: 
The power of darkness in the 'daylight' of today is even worse than the darkness of before ... We claim that today we are Christian and we are in the daylight, but the behaviours emerging today, if you compare with before, are much much worse.

The elder talked about how past attempts to revive customary practices had gone amiss, and how everyone must work to 'pull up' kastom and the values of respect and honour:

Those [customary practices] that are bad; we will throw them out, for example, poison and killing people. But we must take hold of those we think will help us bring back respect and honour to our island ... You need to pull all these things and you will see our lives grow and rise up ... You must try to pull back honour and respect ... Kastom is our identity. We don't know our future ... Identity shows that this is your place.

For the elder, the value of place and time-honoured modes of respect were crucial to navigating an uncertain future. Like the chief, who talked of a selective approach to the incorporation of 'good' foreign items and practices, the elder advocated a selective approach to customary behaviours, seeking to reject 'bad' kastom associated with black magic and conflicts, while retaining the respectful relations seen as underpinning the ability to live together well. He then invited a several elderly people to the stage to demonstrate ideal marriage prescriptions and avoidance behaviours to the children.

Similar complaints about being strong headed, selfish, materialistic and ignoring respect and avoidance expectations are also levelled at seasonal workers, particularly in association with extramarital affairs that take place when married couples are separated during seasonal work. The Assemblies of God pastor, who was also a seasonal worker, told me:

These behaviours have come from money. People overseas are 'out' of respect; they joke and tease with affines. But it started here and spread outward. If you neglect things, then the next day other things will come in as well ... Money flows in but many problems follow this change. For instance, problems with marriages: before they didn't happen. Families have been broken. When change comes, a lot of other things flow in too, if you're not careful.

Money has a good side and a bad side. Parry and Bloch (1989) famously critiqued the assumption that money is a kind of social acid, inevitably dissolving relations and corroding communitarian bonds. They noted a common tendency across different cultures to subordinate short-term 
acquisition to long-term principles of social reproduction in which the totality of transactions form a general pattern which is part of the reproduction of social and ideological systems concerned with a timescale far longer than the individual life'. The durable house and school fees are justified as moral in so far as they are a means of domesticating money to secure a long-term future for the next generation in a changing economy. However, this household-oriented domestication comes into tension with long-term principles of social reproduction associated with kastom in which reciprocity and respect between clans are paramount.

Li-Lamenu often situate different standards of the good in contradictory temporal terms or telos, like the elder above. Many, especially seasonal workers, emphasise a trajectory in which standards of living are improving and development is being created, promising a prosperous future. Others, often older people, talk of a golden age of 'light' ushered in by missionaries to banish pre-Christian 'darkness', in which people cooperated well in community projects and kept the place clean and wellordered-behaviours that are now seen as in decline. In other contexts, people often evoke a revalorised ancestral past in which people lived well according to time-honoured traditions of kastom and kin-ordered respect. Rather than being taken at face value as descriptions of a former way of behaving, Li-Lamenu statements about idealised pasts, as well as futures, legitimate present and future-oriented actions as more or less compatible with achieving a good life together.

\section{Conclusion: Concrete Contradictions}

Li-Lamenu pursuit of the good life in the twenty-first century is fraught with paradox. Workers leave home for several months each year, citing concern for the household. The quest for a durable house constructed from imported materials is seen as a self-evident moral and material 'good'; however, it has given rise to a number of 'bads', including conflicts over land and a decline in reciprocal and communal work. Likewise, investment in educating children is seen as a means of securing a future, especially when the likelihood of making a living on the land is seen as diminishing; however, it may also make future life more precarious if the next generation fail to attain good jobs. 
Reasoning about the good life is no simple matter of separating good from bad; it requires navigating changing and often contradictory value standards. Such dilemmas may be heightened in the twenty-first century, in which people are increasingly confronted with different moral and material goods, each corresponding with different ways of valuing space and time: development and success in a market economy, Christian and community moralities and enduring kastom ideals of respect and reciprocity between kin.

The affective value of ples remains strong, and the good house may be seen as a way of investing in a long-term future as part of the community. However, the quest for a good house has propelled people towards dispersed residence patterns and more household-based work over reciprocal labour between kin and for the community. Building a house of durable materials entails staking a permanent claim to household occupation of land, thereby exacerbating land disputes and accelerating a process towards more individualised land tenure, which leads to increased worries over scarcity of land for food and commodity production. Further, investment in education points to a future in which Li-Lamenu will become increasingly spatially dispersed and urbanised.

Different valuations of time are often evoked to evaluate things and practices as good or bad. A durable house and school fees, unlike other kinds of expenditure, are valued because they are understood to have lasting benefits in securing the household for future generations. However, particularly for older generations, the quest for the good house and improved standards of living are creating tensions and uncertainties over the possibility of achieving social reproduction and living well together with kin and community. Opportunities for work, and the money that flows in, open up possibilities for both prosperity and disaster. Idealised pasts, as well as a utopian telos of development or modernity, may be evoked to legitimate or critique things and behaviours as more or less conducive to a good life. These different moral and material trajectories are evoked to emphasise particular value standards in an ongoing 'historically extended, socially embodied argument' (MacIntyre, 1984, p. 222) over the good life. Yet, alongside an idealist dialectical inquiry into the nature of the good, a historical and materialist dialectical approach reveals the contested nature of the good, and the concrete contradictions and paradoxes arising in these precarious times. 


\section{References}

Callon, M. (1998). An essay on framing and overflowing: economic externalities revisited by sociology. Sociological Review, 46, 244-69. doi.org/10.1111/j.1467-954X.1998.tb03477.x

France, N. (1953). The jungle drums are quiet. Christchurch, New Zealand: Presbyterian Bookroom.

Gamburd, M. R. (2004). Money that burns like oil: A Sri Lankan cultural logic of morality and agency. Ethnology, 43, 167-84. doi.org/ $10.2307 / 3773952$

Gregory, C. A. (2013). The value question in India: Ethnographic reflections on an on-going debate. HAU: Journal of Ethnographic Theory, 3, 116-39. doi.org/10.14318/hau3.1.007

Jolly, M. (1989). Sacred spaces: Churches, men's houses and households in South Pentecost. In M. Jolly \& M. MacIntyre (Eds), Family and gender in the Pacific: Domestic contradictions and the colonial impact (pp. 213-35). Cambridge, England: Cambridge University Press.

Jolly, M. (1991). 'To save the girls for brighter and better lives': Presbyterian missions and women in the south of Vanuatu: 1848-1870. The Journal of Pacific History, 26, 27-48. doi.org/10.1080/00223349108572645

MacIntyre, A. (1984). After virtue: A study in moral theory. Notre Dame, IN: University of Notre Dame Press.

Martin, K. (2007). Land, customary and non-customary in East New Britain. In J. F. Weiner \& K. Glaskin (Eds), Customary land tenure and registration in Australia and Papua New Guinea: Anthropological perspectives (pp. 39-56). Canberra, ACT: ANU E Press.

Martin, K. (2013). The death of the big men and the rise of the big shots: Custom and conflict in East New Britain. New York, NY: Berghahn Books.

Mauss, M. (2007). The manual of ethnography. Oxford, England: Berghahn Books.

Mitchell, J. (2013). Objects of expert knowledge: On time and the materialities of conversion to Christianity in the southern New Hebrides. Anthropologica, 55, 291-302. 
Parry, J. \& Bloch, M. (1989). Introduction: Money and the morality of exchange. In J. Parry \& M. Bloch (Eds), Money and the morality of exchange (pp. 1-32). Cambridge, England: Cambridge University Press. doi.org/10.1017/CBO9780511621659

Radio New Zealand. (2015). Pam teaches lessons about building. Retrieved from www.radionz.co.nz/international/pacific-news/269786/ pam-teaches-lessons-about-building

Rodman, M. C. (1985a). Contemporary custom: Redefining domestic space in Longana, Vanuatu. Ethnology, 24, 269-79. doi.org/10.1017/ CBO9780511582950.020

Rodman, M. C. (1985b). Moving houses: Residential mobility and the mobility of residences in Longana, Vanuatu. American Anthropologist, 87, 56-72. doi.org/10.1525/aa.1985.87.1.02a00060

Rodman, M. C. (1997). Conclusion. In M. C. Rodman \& J. Rensel (Eds), Home in the islands: Housing and social change in the Pacific (pp. 222-33). Honolulu, HI: University of Hawaii Press.

Smith, R. E. (2017). From colonial intrusions to 'intimate exclusions': Contesting legal title and 'chiefly title' to land in Epi, Vanuatu. In S. McDonnell, M. Allen \& C. Filer (Eds), Kastom, Property and ideology: Land transformations in Melanesia (pp. 327-55). Canberra, ACT: ANU Press. doi.org/10.22459/KPI.03.2017.11

Sykes, K. (2012). Moral Reasoning. In D. Fassin (Ed.), A companion to moral anthropology (pp. 169-85). Chichester, England: WileyBlackwell. doi.org/10.1002/9781118290620.ch10

Taylor, J. P. (2008). The other side: Ways of being and place in Vanuatu. Honolulu, HI: University of Hawaii Press. doi.org/10.21313/ hawaii/9780824833022.001.0001

Tonkinson, R. (1982). Vanuatu values: a changing symbiosis. Pacific Studies, 5, 44-63.

Vanuatu National Statistics Office. (2009). National population and housing census. Port Vila, Vanuatu: Vanuatu National Statistics Office.

Ward, R. G. \& Kingdon, E. (1995). Land, custom and practice in the South Pacific. Cambridge, England: Cambridge University Press. doi.org/ 10.1017/CBO9780511597176 
This text is taken from The Quest for the Good Life in Precarious Times: Informal, Ethnographic Perspectives on the Domestic Moral Economy, edited by Chris Gregory and Jon Altman, published 2018 by ANU Press, The Australian National University, Canberra, Australia.

doi.org/10.22459/QGLPT.03.2018.03 